\title{
Business rescue practices in South Africa: An explorative view
}

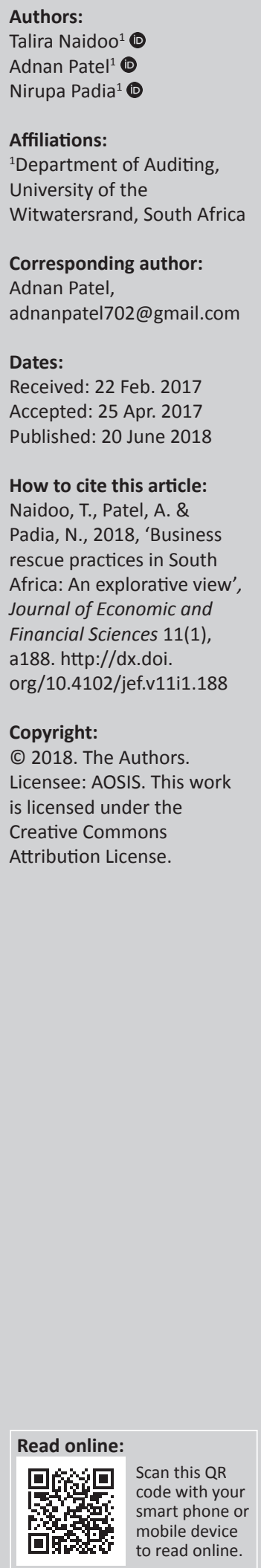

Business rescue proceedings attempt to rehabilitate businesses that are in financial distress. In spite of its importance, there is a seemingly low rate of success of the current business rescue regime (at just $15 \%$ as at June 2016). This article seeks to understand the issues that may be hindering the current rate of success of business rescue proceedings and provides practising accountants (in their capacity as business rescue practitioners) with a better understanding of the issues surrounding business rescue attempts. This will allow them to better perform their duties and give corporates in need of rescue a fighting chance. Through the use of qualitative interviews, the research findings show that there is a lack of clarity of the definition of success, which may be cause for concern. However, in the view of practitioners, the success rate is expected to improve with time. This study provides details on a few key insights into business rescue practices in South Africa, namely, the practitioners' perceptions of success, their perceptions of the trust of stakeholders during the course of business rescue, their perceptions of the impact of the qualifications and experience of the business rescue practitioner, and their perceptions on the preparation of the business rescue plan.

\section{Introduction}

Business rescue proceedings attempt to rehabilitate businesses that are in financial distress and provide them with an alternative to liquidation (Companies Act No. 71 of 2008, s128[1][b]). This is intended to enhance the viability of those businesses, as well as the economy as a whole. A successful rescue will encourage entrepreneurship and growth of the private sector of the economy (Kaulungombe 2012). The business rescue provisions of the Companies Act aim to rescue the business (Bradstreet 2011a). This article, through an investigation of the issues facing the business rescue regime, will provide insight to practising accountants in their capacity as business rescue practitioners.

Prior to business rescue provisions being enacted, judicial management was used for this purpose, but this was traditionally seen as a precursor to liquidation (Levenstein 2008). The business rescue provisions introduced in 2008 brought South African company law in line with international provisions for corporate turnarounds (Levenstein 2008) and aimed to address the shortcomings inherent in judicial management (Loubser 2010). Despite the provisions made in the Companies Act to rehabilitate businesses, business rescue proceedings do not always succeed in rehabilitating the company, as reflected by the low rate of success provided by the Companies and Intellectual Properties Commission ('the Commission') (The Commission 2014; 2015b). The Minister of Trade and Industry acknowledges that the regime has a number of shortcomings that have come to light in the implementation of business rescue, such as 'sanctions applied to business [rescue] practitioners and the regulation of their activities' (The Commission 2014:6).

The purpose of this article is to elicit key insights on the current practice of business rescue in an attempt to understand the regime better and thereby improve on its success. The findings of this study explore the following areas: the practitioners' perceptions of success, their perceptions of the trust of stakeholders during the course of business rescue, their perceptions of the impact of the qualifications and experience of the business rescue practitioner, and their perceptions on the preparation of the business rescue plan.

\section{Literature review Business rescue provisions}

The provisions for business rescue in the Companies Act are vital to the functioning of a healthy economy (Kaulungombe 2012). There are two requirements for the use of business rescue provisions: the company must be financially distressed and there must be a reasonable prospect 
of rescuing the company (Companies Act No. 71 of 2008, s129[1]). 'Financial distress' refers to the appearance that the company will not be able to pay its debts as they fall due in the following 6 months or that the company will become insolvent in the following 6 months (Companies Act No. 71 of 2008, s128[1][f]). Business rescue can be entered into voluntarily by the company or applied for by creditors, shareholders and employees (affected persons) (Companies Act No. 71 of 2008, s128[1][a]). The Association of Chartered Certified Accountants states that the objectives of business rescue proceedings are:

\begin{abstract}
... to save the company as a going concern. If this is not possible, then the secondary object or goal is to restructure the company in such a way that shareholders and creditors will still get a return on their investments, which is better than the return that they would have received should the company be liquidated. (ACCA 2014)
\end{abstract}

The commencement of business rescue proceedings, as facilitated by the business rescue practitioner, grants a temporary moratorium on most legal proceedings against the company, including enforcement action against the company and claims in relation to any property in the company's possession (Companies Act No. 71 of 2008, s133). The practitioner must commence the proceedings by investigating the affairs and financial position of the company and determine whether there is a reasonable prospect of rescuing the company (Companies Act No. 71 of 2008, s141) (this is despite the company or affected person making its own assessment prior to entering into business rescue). If no such prospect exists, the practitioner must inform the affected persons and the court. The practitioner must then apply to the court for the cessation of business rescue proceedings and the commencement of liquidation proceedings (Companies Act No. 71 of 2008, s141[2]). Thus, the business rescue provisions would assist the company in bringing itself out of financial distress and would be controlled and overseen by the business rescue practitioner.

\section{Success of business rescue processes}

Despite the provisions made in the Act, business rescue proceedings do not always succeed in rehabilitating the company - only $12 \%$ of the businesses that entered into business rescue between May 2011 and March 2014 concluded these proceedings successfully (The Commission 2014), and up to and including June 2015 this success rate was $13.6 \%$ (The Commission 2015b). As at the end of June 2016, this had increased to $15 \%$ (The Commission 2016). 'Success', in this instance, refers to 'substantial implementation' of the business rescue proceedings (The Commission 2014). 'Substantial implementation' refers to the business having substantially carried out the activities that were set out for it to achieve through the duration of business rescue in the business rescue plan (The Commission n.d.).

While the regime may be an improvement on its predecessor (judicial management), there are evidently low success rates of business rescue. There has also been a reduction in the number of liquidations and this is 'probably as a result of more financially distressed companies considering the business rescue route' (Hubbard 2013). This shows the impact that the regime has had in preventing potentially unnecessary liquidations.

Several factors have been identified from the literature as contributing to the low rate of success; these include the nature of the relationship between practitioner and management (Levenstein 2008), the lack of availability of funding (Olivier 2014), the relevance of the qualifications and experience of the practitioner (as per section 138 of the Companies Act [2008]), the inconsistency of court judgements, lack of prompt action, the impact of international provisions (The Centre for Advanced Corporate and Insolvency Law 2004) and the rights of affected parties. This article will focus on a few of these key issues to establish their significance and existence, based on South African business rescue practitioners' perceptions.

\section{Business rescue plan}

Upon commencement of business rescue (whether voluntary or as a result of application by an affected person), a business rescue practitioner is appointed to conduct the business rescue proceedings. This practitioner must be of good legal, accounting or business standing; must be licenced by the Commission; must not be on probation or disqualified from acting as a director; and must not be related to the company (Companies Act No. 71 of 2008, s138). The business rescue practitioner has full management control of the company, may delegate any power or function to a person who was part of the board of directors of the company, may remove a person of the management of the company from office and is responsible for the development and implementation of a business rescue plan (Companies Act No. 71 of 2008, s140). Once appointed, it is the practitioner who will facilitate the business rescue proceedings through a business rescue plan.

The formulation of the business rescue plan is one of the most significant and urgent duties of the practitioner. The plan must be published by the practitioner, and within 10 days of the publication of this plan, the practitioner must convene a meeting of creditors in which he or she introduces the plan, informs the attendees whether there is still a reasonable prospect of rescuing the company, gives representatives of employees an opportunity to address the meeting and conducts a vote on any amendments, adjournments and preliminary approval of the plan (Companies Act No. 71 of 2008 , s147 \& s148). The plan must be approved by $75 \%$ of the creditors' voting interests and $50 \%$ of the independent creditors' voting interests (Companies Act No. 71 of 2008, $s 152[2])$. This shows the consideration of stakeholders in the development of the plan. The prompt acceptance of the plan is of utmost importance in the success of the rescue (Lamprecht 2008). Once approved, the plan is binding on the company, the creditors and holders of securities (Companies Act No. 71 of 2008, s152[4]). The company, under the supervision of the practitioner, must take all necessary steps 
to attempt to satisfy any conditions on which business rescue is contingent and implement the plan (Companies Act No. 71 of 2008:s152[5]).

\section{Qualifications and experience required}

Given the importance of the business rescue plan, as outlined above, it is crucial that skilled business rescue practitioners manage the business rescue process (Bezuidenhout 2012). A factor identified as contributing to the failure of business rescue is the fact that, at present, there exist no clear requirements in South Africa for qualification as a business rescue practitioner (Pretorius 2013). Business rescue practitioners are locally claimed to be 'flying blind' (Pretorius 2013:4). The risk is that these practitioners do not know the reason for business failure, do not understand the warning signs present (Pretorius \& Holtzhauzen 2013) and thus do not address these issues appropriately in the plan. At present, there is no clear framework against which to perform their duties and this may accordingly be a contributing factor to the low success rate of business rescue, as practitioners may be unable to identify the appropriate warning signals or to incorporate these appropriately into the plan. Qualification, for persons of good legal or accounting standing, amounts to a course addressing knowledge and skills that needs to be attended by practitioners (Pretorius 2013).

There have also been a large number of people inappropriately acting as business rescue practitioners, because it is viewed as a lucrative practice, and the current 'ad hoc licensing methodology adopted in South Africa' contributes to the existence of practitioners who are ineffective (Pretorius \& Holtzhauzen 2013). Finch (2005) identifies, as a critical aspect of a good corporate rescue regime, expertise 'in making commercial or financial judgments and in devising strategies that advert to all creditor interests' (Finch 2005:385). Conducting corporate rescue will involve many different areas of expertise (Finch 2005) and complex competencies to perform this 'emergency-ward business' (Pretorius 2013:2), but a wide range of expertise in many areas of business is not currently a requirement for qualification as a business rescue practitioner. The lack of expertise and lack of clear commitment to rescuing the company, in the manner envisaged in the Companies Act (2008), may contribute to inappropriate plans that do not appropriately address the risks faced by the company. In addition, the expertise and knowledge of the practitioner is especially important given that he or she is able to exercise the powers of management and is responsible for the development of the business rescue plan discussed above.

\section{Balancing the rights of stakeholders}

As per Section $7(\mathrm{k})$ of the Companies Act, a company is required to balance the rights and interests of all relevant stakeholders and provide for the efficient rescue and recovery of the financially distressed company (Companies Act No. 71 of 2008). Business rescue provisions generally recognise the value of the business as a going concern, thereby catering for a wider variety of interests and moving away from primarily serving the interests of creditors (as per the judgement made by Claasens 2012). Thus, it can be seen that the provisions of the Companies Act (2008) contribute to the functioning of a healthy, balanced economy.

A good working relationship between the practitioner and management is understood to be crucial to successfully turning around a financially distressed company. A relationship of trust and a cohesive vision shared by management and the practitioner are imperative to success (Levenstein 2008). Directors may be distrustful of business rescue practitioners, as they may see the practitioner's main incentive as satisfying the banks' interests rather than rescuing the company (Finch 2005). It is, however, noted that changes in the senior management team may have a role to play in a successful recovery, as this may be a means of restoring stakeholder confidence (Smith \& Graves 2005). Regardless of these issues, it is necessary that the practitioner and management work together to meet the objective of rescuing the business and providing the best possible outcome for all stakeholders.

Regarding the management of these stakeholder rights, it must be borne in mind that the opportunity afforded to, for example, employees and a single shareholder (as 'affected persons') to bring forward an application for business rescue is not comparable to any other rescue regime (Loubser 2010). While shareholders have every right to be involved in corporate rescue procedures because they have a 'real interest in the outcome' (Loubser 2008:372), shareholders do not necessarily have all the information required for an application and may not be able to meaningfully participate in the development of a rescue plan (Loubser 2010). Furthermore, disgruntled employees have the power to apply to the court for the company to be placed under business rescue (Loubser 2010), even if this is not the best course of action for the company. This opportunity given to individual shareholders and employees may result in there being a lack of commitment to the business rescue plan by the other stakeholders, and this may ultimately cause the proceedings to be unsuccessful. Finch (2005) identifies commitment to the rescue enterprise and the varying incentives each person involved has to pursue the rescue of the enterprise. The success of the rescue is dependent on and would be to the benefit of all the stakeholders of the company and the business rescue proceedings.

\section{Summary of literature review}

It is apparent that business rescue proceedings are, in the present state, not very successful, even when success is only measured by the substantial implementation of the business rescue plan. Certain critical factors for success are not necessarily considered prior to the institution of business rescue proceedings. The level of qualification and expertise of the business rescue practitioner has been singled out as a major factor that may contribute to the failure of business rescue, as thus far there are no clear requirements for 
qualification as a business rescue practitioner. The unique provisions of the South African business rescue regime may cause its lack of success - that is, certain provisions impede the legislation from allowing for the objective of business rescue to be met - such as granting too much power to a single shareholder or employee and affording the practitioner full management control of the company, or the execution of a comprehensive business rescue plan in spite of other legislative challenges. As a result of the identification of these potential factors and the impact they have on the regime and the health of the economy, it is necessary to further investigate and understand these crucial factors, in order to gain a deeper insight into and understanding of the current regime. This insight is elicited from the viewpoint of practitioners, as these are the people who are involved in business rescues and best placed to provide meaningful dialogue on the matter.

\section{Methodology}

This study is qualitative and exploratory in nature, as the results are formulated based on the insights and experiences of business rescue practitioners. A qualitative method was used, as it was necessary to gain deep insight into key issues. Interviews were used to extract the views of business rescue practitioners with experience (having more than 10 years of experience). The literature reviewed pointed out some of the potential shortcomings of the regime, from which themes were developed, which then formed the basis for an interview agenda. The transcripts from these interviews were coded with reference to common themes in order to address the key sub-questions of this study. Business rescue practitioners have been selected as constituents of the population as they are likely to have the most relevant knowledge for the study, as they facilitate business rescue proceedings in South Africa. Because of the use of this purposive sampling, interviews were deemed to be the most appropriate method of gleaning deep insight into the key issues impeding the success of the regime. The length and number of interviews (together with constant comparison) led to theoretical saturation being achieved (Creswell 2007; Willig 2008).

The criteria for the selection of participants in the study focused on experience and selection of practitioners who were best placed to provide deep insight into the issues facing the regime. From the 85 experienced and senior registered business rescue practitioners based in Gauteng (as at 31 March 2014), a total sample of 13 were selected (Chen, Danbolt \& Holland 2014; O'Dwyer, Owen \& Unerman 2011; Rowley 2012) from the Commission's database, as data saturation was expected to occur at this point. Interviews were conducted in Gauteng between June 2015 and November 2015. Interviewees comprised business rescue practitioners of different backgrounds (based on information available from the Commission [The Commission 2015a]): six practitioners from an accounting background, one member of the Institute of Directors, two business consultants, two attorneys, one financial advisor and one other professional.
Data collection and analysis made use of a continually iterative process of interview responses being considered in terms of the literature and each other (Willig 2008). The authors alternated between analysing interview data and reading literature based on the emerging themes (Willig 2008). The data was processed using a systematic set of procedures to derive findings (O'Dwyer et al. 2011). The use of the standardised interview agenda allowed for comparisons between responses of different participants to be made. In addition, the research was performed using semi-structured interviews, which allowed interviewees to talk freely about the topic, which, in turn, allowed for a deeper understanding of the interviewees' practice and perceptions of business rescue (Holland 1998).

The transcripts of the interviews were analysed through a formal process of data reduction and data verification (O'Dwyer et al. 2011). Data reduction occurred where key themes were established (O'Dwyer et al. 2011) through a detailed reading of transcripts and rereading of the literature. Themes were then individually coded to assist with analysis (Rowley 2012). Open coding was conducted first, in which the data was segregated into categories and common themes, followed by axial coding, in which relationships between categories were identified (including an identification of the central phenomenon and surrounding conditions), and finally selective coding, in which the categories and their interconnections were considered together, with connections being drawn between different categories (Creswell 2007; Leedy \& Omrod 2013). Consideration of any apparent contradictions within a specific transcript or between interviewees was also made (O'Dwyer et al. 2011). In addition, the responses were considered in conjunction with the literature to identify similarities and differences. Once theoretical saturation occurred, theory was then developed from the coded data. Theoretical saturation was deemed to have occurred when deep insight was gleaned on the key focus areas and when no new insights were developed from further interviews. To ensure that the findings of the research were more reliable, interviewees were sent a transcript of the interview to review and make any additions or corrections (Leedy \& Omrod 2013). External validity of the study was also established through a peer review process wherein the classification and coding was assessed (Rowley 2012).

\section{Findings}

Through the use of the above methodology, key insights were gleaned on the factors impeding the current rate of success of the business rescue regime. It is apparent that business rescue proceedings are, in the present state, not very successful, even when success is only measured by the substantial implementation of the business rescue plan. The perception of the current success rate (and future expectations thereof) is considered first. Secondly, issues related to the preparation and execution of the business rescue plan are considered. The perceptions of practitioners on the relevance and impact of qualifications and experience are then considered. The last key focus areas of this study are the impact of the relationship 
between business rescue practitioners and management of the company, as well as the interests and impact of other stakeholders.

\section{Perceptions on success}

Sections 2.1 to 2.5 above highlighted that the business rescue regime does not appear to be very successful, and it identified certain factors that may have a bearing on this success rate. This section explores the practitioners' views on the success rate, the meeting of the objectives of the regime and the success rate expected going forward.

A large majority of interview participants felt that, without business rescue, there would be unnecessary liquidations, with only two participants of the view that this would not be the case. This reflects on the impact that business rescue may have on corporate rescues and supports the literature, which states that business rescue reduces the number of liquidations and assists in maintaining a greater tax base from which government generates revenue (Kaulungombe 2012). Of the two participants who did not believe that business rescue prevented unnecessary liquidations, one noted the following:

'Sometimes there should be liquidation, because when the economy is booming, some companies make money because the tide is high and some of these may need to be eliminated.'

Another practitioner, however, explained that 'there was no other alternative' and that 'business rescue has filled a big hole where there wasn't actually a methodology to restructuring'. This shows that business rescue has a role to play in assisting ailing businesses in need of rescue and that the regime has contributed to meeting the objectives of the Companies Act.

When the participants of the study were asked whether business rescue proceedings met their intended objective of rehabilitating companies that were in financial distress, less than half of them felt that this was true. Some participants did not provide a clear answer to the question posed and three participants felt that while the proceedings could meet their intended objective, the provisions were easily abused. Another practitioner stated that the regime should not have been called 'business rescue', as it creates the perception that 'you are going to rescue something and it is going to come out on the other side fine and strong', which does not cater for part $b$ of the definition (i.e. a return better than liquidation).

Some practitioners also explained that the rescues they had performed were successful because they were selective about which cases they took on (it is notable that the majority of practitioners interviewed seemed to have well-established business rescue practices and may have been in a position to be able to afford to be selective, while a less established practitioner may not be in a position to do so). A practitioner remarked that some people think it is a 'natural progression to use business rescue and, if that doesn't work, then go into liquidation - but some entities should go straight into liquidation'. This supports the literature in that not every business is a candidate for business rescue (Olivier 2014). This also shows that there should be careful consideration of whether a distressed company is rescuable before it is placed under business rescue.

In a follow-up question, asking specifically about success (as opposed to simply meeting of intended objectives), the majority of participants did not provide a clear answer on whether they believed that business rescues are generally successful. Of those that did answer clearly, only half felt that business rescues were generally successful, which reflects the fact that there exists some uncertainty on the success of the regime. One participant explained that many statistics (on the success rate of business rescue) have a 'flawed premise' (in terms of the way in which success is defined to produce these statistics), but if business rescue's success rate were compared to the success rates of similar regimes around the world, it would be successful. Another practitioner also felt that the current statistics on business rescue success were incorrect and commented that the statistics reflected that ' $15 \%-17 \%$ ' of business rescues were successful but failed to show that only ' $50 \%$ of plans get approved'. This is in contrast to the literature, which shows a $12 \%$ success rate (The Commission 2014) up until 31 March 2014; 13.6\% up until June 2015 and 15\% as assessed in June 2016 (The Commission 2016).

When asked to define success as it relates to business rescue, the responses of practitioners varied widely. An interviewee remarked that this was a 'grey area'. One practitioner felt that a successful business rescue resulted in a sustainable business, with debts addressed and stakeholder expectations met. Other practitioners explained that it was the successful implementation of the business rescue plan that constituted success. Some practitioners referred to the definition (and its implied objectives) per the Companies Act, and two others felt that affected parties receiving more than they would have under liquidation constituted success. These differing definitions are directly in contrast to the definition of success implied by the Commission, which measures the success rate based on the 'notices of substantial implementation' filed. This lack of clarity, however, shows that business rescue may actually be more successful than it is currently perceived to be.

Most practitioners felt that the success rate of business rescue would improve over time, because of better understanding of the regime. One practitioner did not, however, think the success rate would improve, as it is currently in line with that of similar regimes in other jurisdictions in the world. Other participants observed that '... many boards have heard of business rescue but don't know what it means' and that, as publicity and the number of court judgements increase, awareness will grow and the success rate will improve. This is because an increased awareness may lead to boards applying for business rescue earlier on, leading to a better chance of success for the rescue. This increased awareness may also play a role in removing the stigma associated with business rescue and remove its close association with 
liquidation, which may increase the availability of funding for the business under rescue.

The findings of this section show that statistically business rescue proceedings are not highly successful but that they do serve a role in meeting the objectives of the Companies Act and contributing to the overall health of the economy. It is expected that, with time, the success rate of business rescue will improve.

\section{Perceptions on preparing the plan}

The literature showed the importance of the business rescue plan and the crucial role it plays in the success of the business rescue proceedings. When practitioners were asked to rank how influential a variety of factors were on the success of business rescue, a comprehensive business rescue plan with which to rescue the business ranked fairly highly, suggesting that the comprehensiveness of the plan has a significant bearing on the success of the business rescue. All practitioners found a comprehensive business rescue plan to be of importance, which highlights its importance in facilitating the rescue. A participant stated that the business rescue plan was the 'single-most important aspect of your business rescue' and was the 'foundation of the business going forward'.

It was also noted by participants that the plan should be 'equitable to all parties', must be 'sustainable and must not be discriminatory'. Participants' remarks on the plan included 'the simplest plans work the best' and that the plan must 'stay away from grey areas'. Another participant noted that the plan has to withstand some degree of scrutiny because creditors have to approve it. One of the key issues, as identified by one participant, is to allow the creditor to be able to compare the return from a rescue as a dividend versus the return from liquidation. This practitioner also explained that an independent expert should be used to perform valuations and that the plan should give some visibility into the future. This indicates that reliance will be placed on the plan and emphasises the importance of its appropriate preparation.

Creative strategies with which to rescue the business was also ranked highly by most participants as a factor that was highly influential on the success of business rescue proceedings. This suggests that creative strategies may have a significant influence on the success of the business rescue. This reiterates the idea that boilerplate strategies will not enable a successful rescue.

Many difficulties in developing the plan were explained by practitioners, such as having a long-term vision but needing to use short-term steps to see it through, and the fact that various assumptions had to be used. The difficulty resulting from assumptions was reiterated by a practitioner pointing out the fact that forecasting had to be used. Another difficulty noted was putting together a document that is compliant with the Companies Act but understandable by the ordinary businessman. 'A good plan has a long-term view, but has short term milestones'. This participant explicated that the problem is that the plan is done as a 'one-year thing, which may not create a sustainable business'. It was also stated that there are some plans that use a boilerplate template, which does not address the strategy or economics of the company being rescued, and that a robust, appropriate business rescue plan should 'properly combine business strategy, restructuring measures and the legal protections of Chapter 6 [of the Companies Act] to rehabilitate the company'. This shows that there are several intricate considerations that need to be made in developing the business rescue plan and that adequate time needs be dedicated to it.

It was also observed that companies enter business rescue 'too far down the road'. Lack of information and lack of transparency were also pointed out as difficulties, as was prejudice to business rescue from major creditors or a lack of understanding by creditors. The fact that management has to run the business and give the practitioner information to populate the plan was also noted as a difficulty, as was the difficulty in getting information from management, while one practitioner considered the fact that management may not like the plan to be a difficulty. It was explained that a lack of quality in the information provided also presents a difficulty and that the use of an audit firm to verify whether information is valid may be necessary. The fact that both legal and accounting competencies are required to develop the plan was also mentioned as a difficulty, which links to the next section, which explores the need for the practitioner to have a multitude of competencies. The lack of quality information and the lack of assistance from management is a significant difficulty in conducting a successful business rescue.

The majority of practitioners ranked an extended time for the preparation of the business rescue plan highly, suggesting that the current restrictions thereon may be preventing the current regime from achieving success. Three practitioners, however, did not place importance on this factor. Most participants felt that a longer time should be available for the preparation of the business rescue plan and a few explained that they had been able to complete very few plans within the allocated 25 days. Two did not feel that a longer time was necessary, while many also explained the possibility of applying for an extension, with creditor approval, and one stated that because the Companies Act provided this mechanism an extended time was not necessary. One practitioner explained that while 25 days is not sufficient, the Companies Act should also not provide for a longer period, because 'there is a mechanism whereby you can get an extension, but the extension is becoming the norm'. It was explained that it is a good thing 'to put time limits and procedures on these things'. One practitioner explained, however, that 25 days is not sufficient because 'if you publish a plan, it must work' and because ' $80 \%$ of normal creditors don't even understand the difference between debt counselling, business rescue and liquidation', and this needed to be explained before they granted permission for the plan 
to be extended. Another practitioner commented that the practitioner needed to think 'five years down the line' but had only 25 days in which to do so.

A few practitioners stated that the time allocated to developing a rescue plan should be dependent on the size and complexity of the business, with one suggesting that the time allocation be linked to the Public Interest Score of the company. This is because a greater amount of time would be required where there is greater complexity and size, because of additional considerations that need to be made. An interviewee, however, explained that the board itself must consider whether there is a reasonable prospect of rescue and that this evidence provided by the board should be used to develop the business rescue plan. This practitioner, however, explained that that in trading conditions in South Africa at present, this is unrealistic, because there are not good practices regarding corporate governance and it is not possible to get information needed for the plan in the required 25 days. Thus, additional time is needed for suitable business rescue plans to be drawn up.

This section has highlighted the importance of the plan and the difficulties faced in creating it. While creative strategies are helpful, the lack of quality information that is sufficiently forward-looking is a major stumbling block to the success of the regime. In addition and as a result of these difficulties, a longer time for the preparation of the plan may be needed.

\section{Perceptions on experience and qualifications required}

The literature highlighted that business rescue practitioners may have insufficient expertise to successfully conduct business rescue proceedings. On average, practitioners ranked the experience of the practitioners (in general) in conducting business rescues as highly important. The qualification of the practitioner was, however, ranked lower, suggesting that experience is more influential on the success of business rescue than the qualification of the practitioner. One practitioner commented that 'the real qualification is qualification by experience'.

Many practitioners felt that business rescue practitioners (in general) were not adequately qualified to conduct business rescue proceedings. It was, however, pointed out that 'there are some very well-qualified and competent practitioners and a large number who are hopelessly underqualified'. One practitioner pointed out that the business rescue regime is only 3 years old and that the practitioner was being asked to 'handle a complex legal process in a difficult environment without a regulatory framework'. Another practitioner stated that there is 'just a complete lack of competencies'. This shows that practitioners may lack the necessary competencies, in terms of knowledge and experience, to conduct business rescue proceedings.

When asked if there were any requirements that they would like to be introduced into the criteria to qualify as a business rescue practitioner, practitioners made two main suggestions. Firstly was the issue of experience - one practitioner explained the importance of experience by stating that 'without practical experience, it is like learning to drive a motor car while sitting at your desk'. It was pointed out that 'very few business rescue practitioners have run companies themselves' and that there is 'no replacement for experience'. A practitioner explained that there are many issues in business rescue that require different skills and, while not everybody can have all of them, 'experience is a good remedy for fixing up a lot of the shortfalls'. It was suggested that the problem of a lack of experience be addressed by the implementation of a requirement for junior practitioners to serve an apprenticeship with senior practitioners, which could take the form of a joint appointment. One practitioner also suggested that reference checks on practitioners include the validity of relevant experience.

The second suggestion related to additional qualifications. While one practitioner explained that more qualifications similar to the CA (SA) or LLB designations would be beneficial (as is the requirement in Australia, as an example), it was also suggested that a specialist course form part of the criteria to qualify as a business rescue practitioner. One practitioner suggested that an accounting degree coupled with specialist courses would 'provide the best launching pad', while another stated that a financial or legal qualification combined with a course should form part of the requirements. This practitioner stated that while practitioners may be qualified as attorneys, auditors or liquidators, they lack experience. These views support the literature, which showed that there are no clear requirements for qualification as a business rescue practitioner (Pretorius 2013). An interviewee pointed out that there is a flaw in performing business rescue from a purely accounting and legal perspective. One participant went so far as to state that there should be 'fewer liquidators and more experienced businessmen', while another stated that 'you need a lawyer and an accountant' and suggested this be addressed by joint appointments. This re-emphasises the need for greater experience and the need for that experience to be widespread.

Another participant, however, stated that there needed to be competence on the part of business rescue practitioners in four main areas, because of the multidisciplinary nature of business rescues: finance, accounting and tax; management; law; and ethics. The identification of the multidisciplinary nature of business rescue supports the literature, which states that conducting corporate rescue involves many different areas of expertise (Finch 2005). This shows the need for greater requirements to be allowed to qualify as a business rescue practitioner.

\section{Perceptions on trust}

The importance of balancing the rights of all stakeholders was highlighted by the literature, as well as the importance of a good working relationship between the practitioner and management. When asked about the relationship of trust 
between management and the practitioner and its influence on the prospects of the company's rescue, on average, the practitioners ranked this to be fairly influential, showing its importance and supporting the literature.

One practitioner who ranked this factor to be less influential on success explained that 'trust has no place in business rescue'. Despite this, there was general consensus amongst interviewees that the relationship between the practitioner and management will have a significant impact on the prospects of the company's rescue. This supports the literature, which states that a good working relationship between the practitioner and management is the key to a successful turnaround (Levenstein 2008). Some participants explained that there is some level of reliance on management, because the practitioner is not an expert in every field, but it was also cautioned that healthy scepticism on the part of the practitioner is important and that, while management and the practitioner must work as a team, the practitioner cannot be 'beholden' to management. It was emphasised that the relationship between management and the practitioner must be highly ethical and must have clear goals.

It was also explained that, while the practitioner does have to work with management, if the practitioner finds management to be 'incompetent and lying' or frustrating implementation of the plan, the practitioner can remove management. This participant pointed out that the Companies Act allows for the removal of a person as director but not the removal of the person as an employee of the company. This suggests that, while the person will still retain their employment, they will no longer be able to make managerial decisions. It was stated by another practitioner that the speed of the rescue is enhanced if there is a good relationship between the practitioner and management. Another participant corroborated this view in stating that 'a good cooperative relationship with management is a good ingredient for a successful outcome'. This participant, however, remarked that, if this relationship does not exist, the practitioner must have the courage to remove management. This reflects the importance of the relationship with management and the significant impact it can have on the success of the rescue. This also reiterates the literature, which suggested that a change in leadership may have a positive influence on the rescue of the company.

With regard to other stakeholders in business rescue, one practitioner explained that shareholders cannot be excluded because (unless the company is a big corporate) shareholders may be directors; they may have vested interests in the business and be unable to differentiate between the two different roles they hold. This reiterates the need to include all affected parties (stakeholders). The practitioner further explained that they (shareholders who are also directors) may have a skewed view of the business and that, if they cannot be brought around to the practitioner's way of thinking, the rescue will undoubtedly fail. This reiterates the issue of management delaying the rescue because of mismatched priorities and can be considered to be obstructing the success of the regime.

The findings in this section show the importance of the shared goals of management, the business rescue practitioner and the other stakeholders. The relationship between management and the business rescue practitioner has an important role to play in the success of the rescue, but it is important to bear the interests of other stakeholders in mind when performing the rescue.

\section{Conclusion}

In light of the significance of a well-functioning business rescue regime and the current low level of success (as identified by the Commission), this study highlights that it is necessary to determine whether the current business rescue regime addresses the intended objectives (per the Companies Act) and needs of distressed companies. It is vital that an understanding be gathered on the issues that may be hindering the current rate of success to allow corporates in need of rescue a fighting chance. This study addresses this key area of concern by exploring whether the current rescue regime meets its intended objectives and identifies some obstructions to the success of the regime.

The findings reveal that there is a lack of a clear definition of success, which may (partly) be the cause undermining the effectiveness of the regime. Indeed, business rescue is considered to be more beneficial than its predecessor, judicial management, and this study reflects on the role it plays in reducing unnecessary liquidations. Although the success rate was only measured at $15 \%$ as at 30 June 2016, it is expected that this will improve over time. Three key elements are identified in this study that must be addressed in order to facilitate this greater success of the regime: firstly, the business rescue plan must be carefully prepared and sufficient time must be allowed to do so. The current difficulty in finding reliable information on which to base the plan must be addressed, possibly through the use of audit engagements and there needs to be careful consideration of the prospects of rescue prior to a business rescue being initiated. This study shows that companies often come into business rescue too late and an earlier start to the rescue would increase the chances of success. A better enforcement of current legislation would assist in this regard. Secondly, this study shows that the current requirements to qualify as a business rescue practitioner may be inadequate and may not sufficiently address the need for experience, which has an important role to play in the success of business rescue proceedings. Lastly, this study notes that the relationship between management and the practitioner has an important role to play in the success of the rescue and that, while this needs to be a good working relationship, it cannot be one where the practitioner is beholden to management. In addition, despite the focus on this relationship, the interests of other stakeholders must also be considered. In conclusion, this study shows that certain issues hinder the current success of the business 
rescue regime, which need to be urgently addressed to give business rescues a fighting chance of success. The success rate of the regime is expected to improve over time, as the regime matures and awareness grows.

\section{Further research}

This research report is limited to the success of the South African business regime as legislated by the Companies Act and practitioners involved in facilitating this process. While many studies have been undertaken comparing the South African business rescue regime to corporate rescue regimes of other jurisdictions, this study (and those studies) could be expanded to include the views of practitioners from these other jurisdictions. The study is further limited to business rescue proceedings that commenced before 30 June 2015 and business rescue statistics up until 30 June 2016. A future study could be conducted to evaluate whether the difficulties and issues identified above (as impediments to the current business rescue regime) persist as the regime matures.

\section{Acknowledgements Competing interests}

The authors declare that they have no financial or personal relationships which may have inappropriately influenced them in writing this article.

\section{Authors' contributions}

T.N. authored the background and formal research, A.P. composed the article and N.P. provided insight where possible.

\section{References}

ACCA, 2014, Business rescue proceedings, viewed 28 February 2015, from http:// www.accaglobal.com/za/en/student/acca-qual-student-journey/qual-resource/ acca-qualification/f4/technical-articles/business-rescue-proceedings-in-southafrica---part-1.html

Bezuidenhout, P., 2012, A review of business rescue in South Africa since implementation of the Companies Act (71/2008), viewed 15 November 2015 from http://dspace.nwu.ac.za/bitstream/handle/10394/8822/Bezuidenhout PTJ.pdf?sequence $=1$

Bradstreet, R., 2011a, 'The leak in the chapter 6 lifeboat: Inadequate regulation of business rescue practitioners may adversely affect lenders' willingness and the growth of the economy', South African Mercantile Law Journal 22, 195-213.

Bradstreet, R., 2011b, 'The new business rescue: Will creditors sink or swim?', The South African Law Journal 128(2), 352-380.

Chen, L., Danbolt, J. \& Holland, J., 2014, 'Rethinking bank business models: The role of intangibles', Accounting, Auditing \& Accountability Journal 27(3), 563-589. https://doi.org/10.1108/AAAJ-11-2012-1153

Claasens, C., 2012, Case Number: 2011/35199, viewed 05 April 2015, from http:// www.saflii.org/za/cases/ZAGPJHC/2012/12.pdf

Companies Act No. 71 of 2008, n.d., Companies Act (2008), Government Printers, Republic of South Africa, Johannesburg.
Creswell, J.W., 2007, Qualitative inquiry and research design, 2nd edn., Sage, Thousand Oaks, CA.

Finch, V., 2005, 'Control and co-ordination in corporate rescue', Legal Studies 25(3), 374-403. https://doi.org/10.1111/j.1748-121X.2005.tb00676.x

Holland, J., 1998, Private disclosure and financial reporting, viewed 12 December 2015, from https://dspace.gla.ac.uk/dspace/bitstream/1905/113/1/98-6\%5B1\% 5D.pdf

Hubbard, J., 2013, 'Business rescue: Why companies should do their homework', Finweek, pp. 22-23.

Kaulungombe, K.G., 2012, Business rescue for Zambia: Suggestions for legislative Reform, viewed 28 March 2015, from http://uctscholar.uct.ac.za:1801/view/ action/singleViewer.do?dvs=1428178245221 928\&locale=en ZA\&VIEWER action/singleViewer.do?dvs $=1428178245221 \sim 928 \&$ locale $=$ en_ZA\&VIEWER
URL=/view/action/singleViewer.do?\&DELIVERY_RULE_ID=10\&adjacency=N\&appI 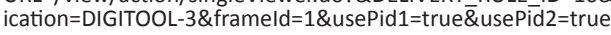

Lamprecht, C., 2008, 'Business rescue replacing judicial management: An assessment of the extent of problems solved', South African Journal of Accounting Research 22(1), 183-196. https://doi.org/10.1080/10291954.2008.11435136

Leedy, P.D. \& Omrod, J.E., 2013, Practical research planning and design, 10th edn., Pearson.

le Roux, I. \& Duncan, K., 2013, 'The naked truth: Creditor understanding of business rescue: A small business perspective', South African Journal of Entrepreneurship and Small Business Management 6, 57-74. https://doi.org/10.4102/sajesbm. v6i1.33

Levenstein, E., 2008, The new business rescue procedure: Chapter 6 of the companies bill, 2008, viewed 26 March 2015, from http://www.health.uct.ac.za/usr/ companylaw/downloads/legislation/WLB_2008-10_Business_Rescue_ Procedure_EL.pdf

Loubser, A., 2008, 'Business rescue in South Africa: A procedure in search of a home?', Comparative International Law Journal of Southern Africa 40(1), 152-171.

Loubser, A., 2010, Some comparative aspects of corporate rescue in South African Company Law, viewed 05 April 2015, from http://uir.unisa.ac.za/bitstream/ handle/10500/3575/dissertation_loubser_a.pdf?sequence $=1$

O’Dwyer, B., Owen, D. \& Unerman, J., 2011, 'Seeking legitimacy for new assurance forms: The case of assurance on sustainability reporting', Accounting, Organizations and Society 36, 31-52. https://doi.org/10.1016/j.aos.2011.01.002

Olivier, J., 2014, 'Business failure: To rescue or not to rescue?', Finweek, 13 November, p. 30.

Pretorius, M., 2013, Tasks and activities of the business rescue practitioner: A strategy as practice approach, viewed 24 March 2015, from http://www.google.co.za/url? $s a=t \& r c t=j \& q=\&$ esrc $=s \&$ source $=w e b \& c d=3 \& v e d=0$ CDYOFjAC\&url $=h t t p \% 3 \mathrm{~A}^{\circ} \% 2 F$ $\% 2 F w w w$.ajol.info $\% 2$ Findex.php $\% 2 F s a b r \% 2$ Farticle $\% 2 F$ download $\% 2 F 110923 \%$ 2F100683\&ei=kfMTVeSNIor1UMjxgdAH\&usg=AFQjCNHKzBBqJqZbHAEocWuojsL e3ciYbg\&bvm $=$ bv.89217033,d.ZWU

Pretorius, M. \& Holtzhauzen, G., 2013, 'Business rescue decision making through verifier determinants - Ask the specialists', South African Journal of Economic and Management Sciences 16(4), 468-485. https://doi.org/10.4102/sajems.v16i4.450

Rowley, J., 2012, 'Conducting research interviews', Management Research Review 35(3/4), 260-271. https://doi.org/10.1108/01409171211210154

Smith, M. \& Graves, C., 2005, 'Corporate turnaround and financial distress', Managerial Auditing Journal 20(3), 304-320. https://doi.org/10.1108/02686900 510585627

The Commission, 2014, Annual report 2013/2014, viewed 24 March 2015, from http://www.thedti.gov.za/parliament/2014/CIPC_AR2014.pdf

The Commission, 2015a, Application for license as business rescue practitioner, viewed 24 May 2015, from http://www.cipc.co.za/index.php/manage-yourbusiness/manage-your-close-corporation/changing-status-your-company/ business/manage-your-close-corporation/chan
application-license-business-rescue-practitioner/

The Commission, 2015b, Status of business rescue proceedings in South Africa June 2015, viewed 03 December 2015, from http://www.cipc.co.za/files/ $5914 / 4488 / 9277 /$ Status_of_Business_Rescue_in_South_Africa_June_2015 version1_0.pdf

The Commission, n.d., Notice of substantial implementation of business rescue plan, viewed 26 March 2015, from http://www.cipc.co.za/files/7113/9359/7090/ CoR125_3.pdf

The Commission, 2016, Notice of substantial implementation of business rescue plan viewed 24 February 2017, from http://www.cipc.co.za/index.php/publications/ business-rescue/

Willig, C., 2008, Introducing qualitative research in psychology, 2nd edn., McGraw Hill, New York. 